\title{
An Investigation on the Bacterial Contents of Natural Springs in a Rural Area of the Middle Blacksea Region in Turkey
}

\author{
Alaa Aqso, Kübra Özkul, Haydar Karakaya* \\ Department of Biology, Faculty of Science and Arts, University of Ondokuz Mayıs, Samsun, Turkey \\ *Corresponding author: hkarakay@omu.edu.tr
}

Received August 07, 2014; Revised November 19, 2014; Accepted November 24, 2014

\begin{abstract}
Bacterial contamination levels of representative 4 natural springs were detected seasonally through indicator bacterial contents in a rural area of Ordu, Türkiye. Total coliform bacteria, enterococi, Escherichia coli and Clostridium perfringens spores were used as the indicator organisms. According to the bacterial parameters, none of the detected springs comply with the standards implemented by the state health authorities. Contamination level of the springs increases with human and domestic animal activities in spring and summer. Using PCR and duplex PCR, samples collected from the most densely contaminated spring, Soğuksu, were analyzed for three pathogenic bacterial groups. After eight-hour enrichment of the samples, positive results were found only for Salmonella spp. In conclusion, this investigation revealed that the natural springs used for drinking water supply in the research area are exposed to bacterial contaminations and the level of contamination increased with settlement density.
\end{abstract}

Keywords: spring water, bacterial contamination, cultural tests, PCR analyses

Cite This Article: Alaa Aqso, Kübra Özkul, and Haydar Karakaya, "An Investigation on the Bacterial Contents of Natural Springs in a Rural Area of the Middle Blacksea Region in Turkey.” Applied Ecology and Environmental Sciences, vol. 2, no. 5 (2014): 123-129. doi: 10.12691/aees-2-5-3.

\section{Introduction}

Natural springs are the locations in which underground water reaches to the surface spontaneously through the fractures of earth strata [1,2]. Under natural environmental conditions, bacterial content of natural springs is extremely poor. Such habitats contain a few heterotrophic and chemolitotrophic bacteria because of poor availability of organic nutrients and lack of sunlight. This makes natural springs a convenient resource of drinking water for rural populations $[3,4]$.

Bacterial communities present in groundwater are divided into two groups: permanent community and temporary community. Permanent community is represented by non spore-producing Gram negatives most of which are members of Acromobacter and Flavibacterium, and Gram positive bacilli including members of Mirococcus, Nocardia and Cytophaga in fewer numbers [5,6]. Using molecular techniques much more bacterial taxa have been found in subsurface habitats $[7,8]$ Temporary community of groundwater, on the other hand, is not continuously growing and it is only temporarily present in groundwater. This community may be divided into two subgroups: i) soil bacteria and ii) the bacteria which are inhabitants of human and warm-blooded animals' body and mainly their gastrointestinal tract.

Even though most nonpathogenic soil bacteria drain through earth strata and rarely reach groundwater reservoirs, they cannot survive there long because of nutrient limitation. Animal originated temporary community is mostly consisted of animal and more often human gastrointestinal community through the reach of digestive system waste into groundwater reservoirs because of dense settlement on the catchment area of groundwater reservoir, untreated deposition and/or incorrect storage of fecal waste and heavy rains help the waste to penetrate deep into the soil [9].

Health risk of temporary community is essentially the reach of human digestive system wastes into groundwater reservoirs by draining through the soil $[2,10]$. Natural intestinal community which is mostly nonpathogenic or rarely pathogenic is not able to survive in the environment long as they die in a relatively short time [11]. Nevertheless they may cause infections if contaminated water is used in this short survival period. In past and present days a number of epidemic incidences caused by waterborne microbes have been reported especially in developing countries [12].

A group of organisms are called index organisms that are used as an indicator of one or more target organisms such as pathogenic strains in a habitat. Index organisms used for monitoring treated water are called indicator organisms. The term indicator organisms are often used in place of both index and indicator organisms [2,12,13,14,15]. Amongst the others, a number of bacteria or bacterial groups such as coliform bacteria, Escherichia coli, enterococci and Clostridium perfringens spores have been used as indicator organisms for fecal contamination of 
water reservoirs [16]. Each group possesses both advantages and disadvantages. In time, coliform bacteria included a number of genus according to the properties of acid and gas forming or only gas forming and $\beta$ galactosidase activity $[15,17]$. The origins of the genus included in coliforms may be only environmental or both environmental and fecal or only fecal [2]. Therefore, an existence of coliform bacteria is not always an indication of fecal contamination. On the other hand, E. coli becomes a better indicator for fecal contamination since it is a natural member of intestinal bacterial community of human and the other warm-blooded animals [15]. Enterococci are also intestinal origin and used as indicators for long term fecal contamination [18]. Clostridium perfringens spores are used as indicators not only for bacterial spores, but also for viruses and protozoan cysts detection in water [19].

Traditional culture detection techniques for bacterial contamination are not effective in some cases such as longer testing time, inhibition of indicator growth by inhibitor of the other bacteria and presence of viable but uncultivable cells. [20,21,22]. In such cases molecular techniques promise more effective detection methods by increasing the limits of detection and shortening the test duration [21]. Commonly used molecular techniques are PCR-based ones such as monoplex PCR, multiplex PCR (m-PCR) and quantitative PCR (qPCR) [23,24,25,26,27]. Using specific primers, multiple loci of a target organism or more than one target organisms can be detected in a single PCR reaction. Quantitative PCR techniques allow detection of presence and quantity of target organism(s). To detect the presence and quantity of targeted organisms, mPCR and qPCR have been applied successfully to both the environmental and clinic samples [20,23,28,29]. A major drawback for molecular techniques for detection of target organisms is its sensitivity that has higher detection limits than that of traditional culture-based techniques [28], [30,31]. Nevertheless, various types of organisms can be detected and quantified by means of molecular techniques.

In rural areas of Blacksea Region, the groundwater which reaches to the surface as natural springs is almost the sole source of drinking water for the inhabitants. It is used as raw water without any treatment. There is no sewage system in this rural area. As a result, groundwater reservoir of the region is open to bacterial contamination with a high health risk which may originate from pathogenic bacterial contaminants. In this study, natural spring water was analyzed for presence of some indicator and pathogen bacteria using traditional culture-based and molecular techniques in Güvenyurt Village (Ulubey, Ordu) as a typical rural area for Middle Black Sea Region of Turkey.

\section{Materials and Methods}

\subsection{Materials}

Water samples, collected from a rural area of Ordu province in Middle Blacksea Region, were analyzed for certain selected indicators and pathogen bacteria. Indicators were total coliforms, Escherichia coli, enterococci and Clostridium perfringens spores while pathogens were E. coli O157:H7, Salmonella spp. and
Campilobacter jejuni. E. coli DH5 $\alpha$ and Salmonella enterica Typhimurium used as positive controls. Güvenyurt Village (Ulubey, Ordu, Turkey) was selected as the research area. 4 natural springs were selected amongst a total of about 35 springs which are used as drinking water supply by inhabitants in the area. Yarımcin and Harmancık springs are located in forested area away from populated area of the village. Yatakyeri spring is located on a lightly populated upper side of the village while Soğuksu spring is situated below the heavily populated area of the village. Locations of all the 35 natural springs of the research area are comparable with those four selected springs.

\subsection{Methods}

\subsubsection{Collection, Transport and Storage of Water Samples}

Water samples were collected to determine changes in bacterial content in four seasons of the year in November 2011, February, May and August 2012. Samples were collected in sterile $400 \mathrm{ml}$ polypropylene vial by means of autoclave sterilized silicon pipe and stored in a cooler bag until the reach of the laboratory [32]. One part of each sample was used for traditional culture tests in the same day, while the other part was stored at $4^{\circ} \mathrm{C}$ until the following day for template DNA preparation.

\subsubsection{Total Coliforms Test}

A certain volume water sample was filtered through a sterile filter (Pall Corp.) with 0,45 $\mu \mathrm{m}$ poor width using a filtration system (Sartorius). The filter then was transferred onto lactose TTC agar plates and incubated at $37^{\circ} \mathrm{C}$ for $24-48 \mathrm{~h}$ [32]. All the lactose positive colonies grown on the filter were counted as a total of coliform bacteria with Pseudomonas spp. [33]. The colonies were counted and the number of bacteria in $100 \mathrm{ml}$ of original samples was estimated. To exclude Pseudomonas spp. from the total coliforms, randomly selected colonies were applied to oxidase test and oxidase positive colonies were excluded from the total number of colonies.

For oxidase test, 2 drops of freshly prepared oxidase reactive (1\% Tetramethyl p-phenylendiamine $\mathrm{HCl}$ in water) were placed on a filter paper and a colony was spread on the filter with a non-chrome loop. The colonies which were coloured into dark blue- purple in $30 \mathrm{sec}$ were taken as oxidase positive [32].

\subsubsection{E. coli Test}

Indole test was applied to find E. coli from the colonies grown on TTG agar plates. Yellowish colonies grown under the filter were inoculated into Tryptophan broth medium and inoculated at $44,5^{\circ} \mathrm{C}$ for $24 \mathrm{~h}$ in a test tube. Occurrence of a cherry-red ring on the surface of the medium was taken as E. coli positive [32].

\subsubsection{Detection of Intestinal Enterococci}

To determine enterococi from the water samples, enterococci specific Slanetz-Bartley selective medium was used. After filtering of a certain volume of water sample, the filter was placed onto the selective agar medium and grown at $37^{\circ} \mathrm{C}$ for $24 \mathrm{~h}$. To confirm the colonies as enterococci, the filter with colonies was transferred to a 
preheated Bile Aesculin Azide Agar plate at $44^{\circ} \mathrm{C}$ for $2 \mathrm{~h}$. The colonies, the colour of which was changed into tin to black, were counted as intestinal enterococci [34].

\subsubsection{Detection of Anaerobic Bacterial (Clostridium sp.) spores}

To find Clostridium sp. spores, solid SPS (iron sulphate agar) medium stored in a vial test tube was melted at $98^{\circ} \mathrm{C}$. Water samples were heated at $75^{\circ} \mathrm{C}$ for $15 \mathrm{~min}$ to kill vegetative forms. Heated water samples were then inoculated into the bottom of the melted SPS medium in a ratio of $1: 1(\mathrm{v} / \mathrm{v})$. This culture was incubated at $37^{\circ} \mathrm{C}$ for $24 \mathrm{~h}$, and blackish coloured growth spots were counted as anaerobic spores $([35,36]$.

\subsubsection{Detection of Indicator and Pathogen Bacteria by PCR}

All the basic molecular biological techniques were carried out according to Sambrook and Russell [37]. PCR amplification was applied to detect pathogen strains of Salmonella sp., E. coli O157:H7 and Campylobacter jejuni in the collected water samples. E. coli DH5 $\alpha$ and $S$. enterica Typhimurium LT2 were used as positive controls. Genomic DNA isolation was carried out according to Park et al. [28]. Standard nutrient broth medium was used for bacterial growth. Pure genomic DNA, environmental DNA and cell-free extracts were used as template in PCR reactions. Cell free extracts were prepared according to Park et al. [28]. Specific primers used in this study were shown in Table 1. Monoplex and multiplex PCR amplifications were applied to the water samples collected from Soğuksu spring which is the most intensely polluted. $1 \mathrm{l}$ of sample water was filtered through a filter with 0,45 $\mu \mathrm{m}$ poor width and cells were resuspended in $1 \mathrm{ml}$ nutrient broth. This suspension was used for either cellfree extract preparation or inoculums for nutrient broth enrichment culture.

Table 1. Sequences of the Primers Used in PCR Analyses

\begin{tabular}{|l|l|}
\hline Names and sequences of the primer pairs (5'-3') & Organism \\
\hline $\begin{array}{l}\text { lacA-F2-A2: CCCGCGCCAATAACAGAATTATCC } \\
\text { lacA-R2-A2: AGAAATGTTTGCCACGGTAGGGG }\end{array}$ & $\begin{array}{l}\text { E. coli and } \\
\text { Shigella [23] }\end{array}$ \\
\hline $\begin{array}{l}\text { campsh-F: CAAGTTGCTACAATCTCAGCCA } \\
\text { campsh-R: GATAACACCATCTTTGCCCACT }\end{array}$ & C. jejuni [28] \\
\hline $\begin{array}{l}\text { eae150-F: GGCGGATTAGACTTCGGCTA } \\
\text { eae150-R: CGTTTTGGCACTATTTGCCC }\end{array}$ & $\begin{array}{l}\text { E. coli } \\
\text { O157:H7 [38] }\end{array}$ \\
\hline $\begin{array}{l}\text { invA3-F: AACGTGTTTCCGTGCGTAAT } \\
\text { invA3-R: TCCATCAAATTAGCGGAGGC }\end{array}$ & $\begin{array}{l}\text { Salmonella } \\
\text { spp. [39] }\end{array}$ \\
\hline
\end{tabular}

\subsubsection{Statistical Analyses of the Data}

Mann-Whitney U [40] (Ruxton, 2006) tests were applied for statistical analyses of the data using SPSS Statistics 17.0 package. Seasonal variations and relationship between contamination density and distance from the settlement area were analyzed separately.

\section{Results}

\subsection{Natural Spring in Research Area}

Initially, the total number of natural springs which are used for water supply by inhabitants was found. Total of 35 springs were found to be used by local population for drinking water supply. Almost all the springs are transferred to the residences through pipes and used without any means of purification treatments. The locations of the springs are scattered through the area from lower to higher altitudes and from less or no populated areas to densely populated areas. Four of the springs were selected to represent all the springs of the area instead of testing all of them.

The spring Yarımcin is located in a non populated forest area at an altitude of $300 \mathrm{~m}$. It is used as an on-site supply especially during hazelnut harvesting in August. Soğuksu spring is positioned below the most populated area of the village at an altitude of $530 \mathrm{~m}$. The spring is used by quite a big part of the population through a pumping and a pipe system. As a representative of the less populated area, Yatakyeri spring has an $850 \mathrm{~m}$ altitude and supplies drinking water to a medium size of population through a pipe system. Lastly, Harmancik spring is located in a forested area at the altitude of $950 \mathrm{~m}$ which is the highest amongst the representing springs. There is no settlement near and above the spring and it is used as water supply to relatively small number of settlers through a pipe system.

Water and environmental temperatures of each spring were measured during sampling. The $\mathrm{pH}$ values were also determined immediately after reach of the laboratory. Temperature and $\mathrm{pH}$ data were shown in Table 2.

Table 2. water and environmental temperatures and $\mathrm{pH}$ values of the springs. Abbreviations: W stands for water $E$ for environment, H for Harmancık, YY for Yatakyeri, S for Soğuksu and YC for Yarımcin

\begin{tabular}{|c|c|c|c|c|c|}
\hline Sampling & \multirow{2}{*}{$\begin{array}{c}\text { Temp. } \\
\text { Time }\end{array}$} & \multicolumn{4}{|c|}{ Spring } \\
\cline { 2 - 6 } & $\& \mathrm{pH}$ & $\mathrm{H}$ & $\mathrm{YY}$ & $\mathrm{S}$ & $\mathrm{YC}$ \\
\hline \multirow{4}{*}{ Nov 2011 } & $\mathrm{W}\left({ }^{\circ} \mathrm{C}\right)$ & 8 & 8 & 11 & 12 \\
\cline { 2 - 6 } & $\mathrm{E}\left({ }^{\circ} \mathrm{C}\right)$ & 4 & 10 & 6 & 3 \\
\cline { 2 - 6 } & $\mathrm{pH}$ & 8,29 & 8,30 & 8,31 & 8,33 \\
\hline \multirow{4}{*}{ Feb 2012 } & $\mathrm{W}\left({ }^{\circ} \mathrm{C}\right)$ & 4 & 4 & 5 & 7 \\
\cline { 2 - 6 } & $\mathrm{E}\left({ }^{\circ} \mathrm{C}\right)$ & 2 & 2 & 0 & 2 \\
\cline { 2 - 6 } & $\mathrm{pH}$ & 8,00 & 8,20 & 7,97 & 8,20 \\
\hline \multirow{3}{*}{ May 2012 } & $\mathrm{W}\left({ }^{\circ} \mathrm{C}\right)$ & 11 & 11 & 11 & 10 \\
\cline { 2 - 6 } & $\mathrm{E}\left({ }^{\circ} \mathrm{C}\right)$ & 13 & 15 & 19 & 15 \\
\cline { 2 - 6 } & $\mathrm{pH}$ & 8,25 & 8,22 & 8,00 & 8,30 \\
\hline & $\mathrm{W}\left({ }^{\circ} \mathrm{C}\right)$ & 15 & 13 & 19 & 17 \\
\cline { 2 - 6 } & $\mathrm{E}\left({ }^{\circ} \mathrm{C}\right)$ & 20 & 22 & 25 & 23 \\
\cline { 2 - 6 } & $\mathrm{pH}$ & 8,30 & 8,00 & 8,20 & 8,30 \\
\hline
\end{tabular}

\subsection{Indicator Bacterial Contents of the Natural Springs}

Selected indicator bacterial contents of the representative springs in the research area were determined by traditional culture technique in November 2011, February, May and August 2012. Parametric values of the parameters enterococci, total coliforms, $C$. perfringens spores and E. coli were shown in Table 3.

Harmancik spring was not contaminated with enterococci and $C$. perfringens spores through the year. $E$. coli was detected in autumn 2011 in only one of the three repeated tests but it was not detected in other three seasons. Coliform contamination was persistent through the year, more heavily in spring.

Yatakyeri spring did not contain any C. perfringens spores through year. Enterococci and E. coli were not detected in winter while they were represented by 
relatively lower numbers in autumn compared with spring and summer. E. coli numbers were 5 to 10 times more than enterococci through year. Total coliforms were detected in all seasons and their numbers in spring and summer increased approximately 50 times to those of autumn and winter.

Table 3. Parametric Values of the Indicator Bacterial Groups Enterocicci, Total Coliforms, C. perfringens Spores and E. coli. "cfu" stands for colony forming units, $C$. perf for $C$. perfringens, $\mathrm{H}$ for Harmancık, YY for Yatakyeri, $S$ for Soğuksu and YC for Yarımcin

\begin{tabular}{|c|c|c|c|c|c|}
\hline \multirow{4}{*}{ Spring } & $\begin{array}{c}\text { Sampling } \\
\text { Time }\end{array}$ & $\begin{array}{c}\text { Enterococci } \\
\text { (cfu/100 ml) }\end{array}$ & $\begin{array}{c}\text { Total } \\
\text { Coliforms } \\
\text { (cfu/100 } \\
\text { ml) }\end{array}$ & $\begin{array}{c}\text { C. perf. } \\
\text { spores } \\
\text { (cfu/50 ml) }\end{array}$ & $\begin{array}{c}\text { E. coli } \\
\text { (cfu/ 100 } \\
\text { ml) }\end{array}$ \\
\hline \multirow{4}{*}{ H } & Nov. 11 & 0 & 53,33 & 0 & 1,33 \\
\cline { 2 - 6 } & Feb. 12 & 0 & 63 & 0 & 0 \\
\cline { 2 - 6 } & May 12 & 0 & 428,67 & 0 & 0 \\
\cline { 2 - 6 } & Aug. 12 & 0 & 60,67 & 0 & 0 \\
\hline \multirow{4}{*}{ YY } & Nov. 11 & 1,33 & 72,33 & 0 & 5,67 \\
\cline { 2 - 6 } & Feb. 12 & 0 & 48,67 & 0 & 0 \\
\cline { 2 - 6 } & May 12 & 61,33 & 3200 & 0 & 460 \\
\cline { 2 - 6 } & Aug. 12 & 40,67 & 2266,67 & 0 & 423,33 \\
\hline \multirow{4}{*}{ S } & Nov. 11 & 11 & 1233,33 & 35 & 47,33 \\
\cline { 2 - 6 } & Feb. 12 & 174 & 656,67 & 0 & 11,33 \\
\cline { 2 - 6 } & May 12 & 97,33 & 4500 & 1,67 & 453,33 \\
\cline { 2 - 6 } & Aug. 12 & 48,67 & 1496,67 & 0 & 316,67 \\
\hline \multirow{4}{*}{ YC } & Nov. 11 & 1,67 & 250 & 0 & 5,33 \\
\cline { 2 - 6 } & Feb. 12 & 0 & 21,33 & 0 & 4 \\
\cline { 2 - 6 } & May 12 & 64 & 1116,67 & 0 & 85 \\
\cline { 2 - 6 } & Aug. 12 & 313,33 & 1763,33 & 0 & 355 \\
\hline
\end{tabular}

Being located below the dense populated area, the most contaminated spring, by the indicator bacteria in the area through the year, is Soğuksu spring. It was contaminated heavily by total coliforms. In respect to contamination density total coliforms were followed by $E$. coli and enterococci respectively. This spring was the one among the representative springs that was contaminated with $C$. perfringens spore in autumn and spring. Winter and summer samples were free of the contamination.
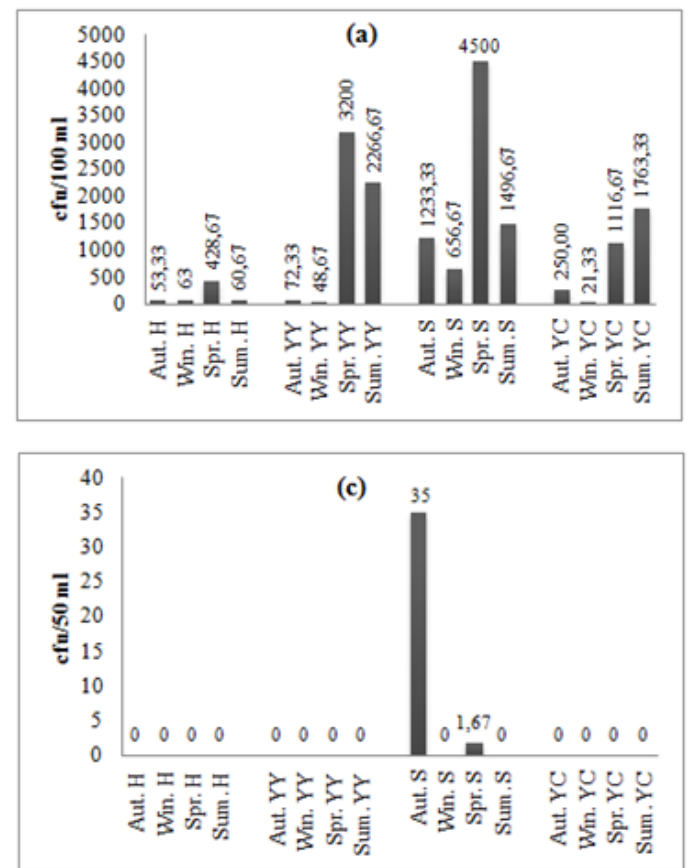

Surprisingly Yarımcin spring was found to be densely contaminated with three of the indicators even though it is located away from the settlement area. It showed no $C$. perfringens contamination like Harmancık and Yatakyeri springs. Enterococci were present in three seasons except for in winter. Total coliforms contamination was found through the year with a lighter density than Soğuksu and Yatakyeri springs. Also E. coli contamination was found through the year (Table 2).

\subsection{Comparison of Seasonal Contents of the Natural Spring}

Enterococci were not detected in Harmancık spring through the year (Figure $1 \mathrm{a}$ ). The other three springs were contaminated with enterococci except for Yatakyeri and Yarımcin in winter. Contamination densities tend to increase in spring and summer. Contrary to Yatakyeri and Yarımcin, Soğuksu was densely contaminated in winter. Even though it is located away from the settlement area, Yarımcin spring was detected to exhibit the highest number of enterococci in summer (Figure $1 \mathrm{a}$ ).

Total coliforms were found in all the seasons in all the springs. The lowest numbers were found in autumn and winter in all the springs. Contamination densities increased both in spring and summer extensively. Soğuksu spring exceptionally exhibited a different pattern of a more dense contamination with a record number in spring at least three times more than those in the other seasons. Contamination densities were consistent with the location of the spring, closer settlement area results in higher contamination density (Figure $1 \mathrm{~b}$ ).

C. perfringens spores were present only in Soğuksu spring. The spores were found in autumn and spring, tremendously higher in autumn. Locating below the densely settled area, the source of contamination was probably from human and/or livestock effect. The other springs were completely free from spore contamination (Figure $1 \mathrm{c}$ ).
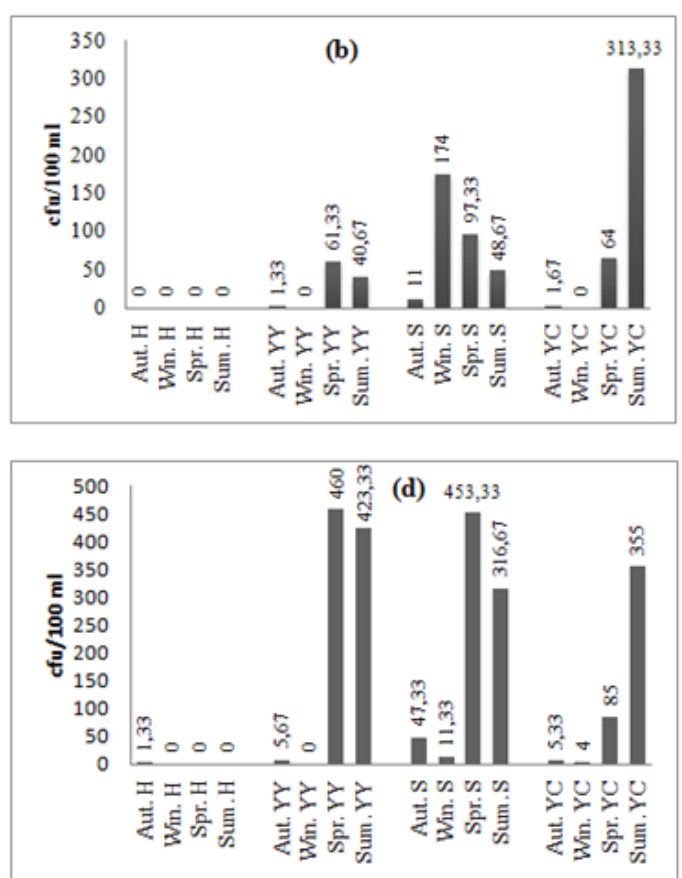

Figure 1. Seasonal variations in number of indicator bacterial parameters in representative natural springs. a) Total coliforms, b) enterococci, c) C. perfringens spores and d) E. coli. Parametric values for each indicator are given over the bar. Data is mean of three independent tests. "cfu” stands for colony forming units 
E. coli was exhibited in all the representing springs. In Harmanckk spring E. coli were found only in autumn, 5 cells were found in only one of the three repeat tests. During the other seasons of the year the spring was completely free of E. coli. The other three springs showed similar pattern of E. coli numbers. Contamination was relatively sparse in autumn and winter and increased substantially in spring and summer. Yarımcin spring was comparatively less affected while Yatakyeri and Soğuksu springs showed a similar higher contamination density (Figure $1 \mathrm{~d}$ ).

\subsection{PCR Detection of Bacterial Strains in the Samples}

Especially rivers, irrigation and recreation waters have been tested for certain bacterial strains by means of PCR and qPCR analyses. The pathogens Campilobacter jejuni, E. coli O157:H7 and Salmonella enterica Thyphimurium LT2 strains were detected by multiplex PCR and qPCR with a reasonable sensitivity [28]. To find sensitivity of such techniques in natural spring water, we also tried to detect E. coli O157:H7, Salmonella spp. and C. jejuni by monoplex and duplex PCR amplification.

Firstly, PCR parameters were optimized by using $E$. coli DH5 $\alpha$ genomic DNA as template and specific primer for E. coli and Shigella spp. Minimally amplifiable genome numbers were found to be 3520 per reaction using pure genomic DNA. Then, PCR amplification reactions were performed using cell free extracts of E. coli DH5 $\alpha$ and S. enterica Typhymurium LT2 as template in PCR reactions, yielding expected PCR products.

Eventually Soğuksu spring which is the most densely contaminated in the area was analyzed for existence of the bacterial groups above by PCR. Exhibiting an intermediate contamination level among the other seasons which was 47,33 cfu/100 ml, autumn samples were used for PCR analyses. $1 \mathrm{l}$ of the sample containing $473 \mathrm{E}$. coli cells were filtered and resuspended in $500 \mathrm{ml} \mathrm{TE}$ tampon. This concentrated sample was freeze-crashed and used as template DNA. No PCR products were amplified even with increased amount of templates.

To supply more template DNAs, 11 of original spring water sample was filtered and inoculated in nutrient broth to enrich bacterial cell numbers. During enrichment $1 \mathrm{ml}$ samples were removed from the culture after 1, 2, 4 and 8 hours after incubation and used for cell free extract preparation. Each sample was tested for PCR amplification using $E$. coli specific primers first. An expected 360 bp PCR product was produced by template from 8 hour incubated culture but no product from earlier samples. Same result was found with Salmonella spp. specific primers. No product was seen in samples from all incubation times with primers for E. coli O157:H7 and C. jejuni. Afterwards monoplex and duplex PCR amplification were applied using E. coli and Salmonella spp. specific two sets of primers using cell free extracts as template from 8 hour enriched culture. 360 bp E. coli and 260 bp Salmonella sp. products were seen as single bands in monoplex PCR, 360 bp and 260 bp two fragments in duplex PCR reactions (Figure 2). This result showed that Salmonella spp. can be detected in Soğuksu spring contaminated with $E$. coli in a density of $47,33 \mathrm{cfu} / 100 \mathrm{ml}$ if only $1 \mathrm{l}$ filtered sample was enriched in nutrient broth at least 8 hours.

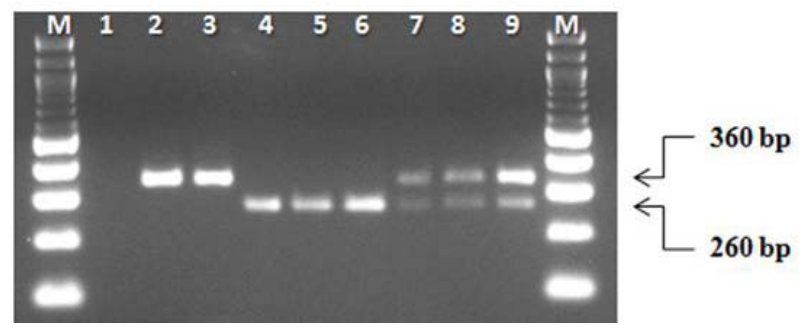

Figure 2. Monoplex and duplex PCR products amplified with E. coli specific lacA and Salmonella spp. specific invA primers. Line 2 and 3 shows lacA monoplex, lane 4-6 invA monoplex and lane 7-9 lacA-invA duplex PCR products. Lanes $\mathrm{M}$ are molecular markers (Biolabs $100 \mathrm{bp}$ DNA ladder)

\section{Discussion}

In terms of the quality of natural springs, the research area represents the rural area of not only Ordu Province but, perhaps also all the middle and eastern Blacksea Region of Turkey. The area exhibits a sparse settlement and natural springs are almost the sole drinking water source, without any treatment in most cases. Not an effective surveillance has been applied in the area, where selected indicator bacterial parameters have been tested in only one station for each village twice in a year [40]. The results of this study showed no potable spring water available in the research area according to the regulation of the health authority [41]. According to these regulations, total coliforms are an indicator for bacterial detection in drinking water. However, some sceptical ideas have been become widespread for these organisms as an indicator because many numbers of coliforms are known to be purely environmental origin [15]. Taking this into consideration, Harmancik spring may be accepted to accomplish the requirements for a drinking water supply provided that a very few contamination with E. coli in summer is omitted (1,3 cfu/100 ml). This result implies that underground water reservoirs located under nonsettled areas are not completely open to bacterial contamination. However, Yarımcin spring which is positioned well away from settlement area exhibited some degree of contamination with enterococci and E. coli as well as total coliforms. Positioning away from settlement area like Harmancık spring, difference in the contamination levels is possibly because of the difference in their altitudes, that the altitude of Yarımcin is $300 \mathrm{~m}$ and Harmancık $950 \mathrm{~m}$. Yarımcin area is probably affected by human activities during hazelnut harvesting in summer and by wild life in winter which is more moderate than Harmancık. Other two springs, Yatakyeri and Soğuksu, are badly open to bacterial contamination in 4 seasons of the year. Soğuksu spring is located below the most densely populated area and therefore is exposed to the worst contamination among the natural springs tested accordingly. Moreover, it exhibited C. perfringens spore contamination in autumn and spring. The results indicate that more human and livestock activities cause heavier bacterial contamination in natural springs of the area.

When only very low level of total coliforms and rare $E$. coli are represented, a seasonal effect comparison cannot 
be meaningful for Harmancık spring. Remaining three springs exhibited a tendency to increasing bacterial contents in spring and summer. When the total of autumn and winter values were compared with those of spring and summer, total coliforms increased considerably in Yatakyeri, Soğuksu and Yarımcin springs. The higher coliform values were seen in spring in Yatakyeri and Soğuksu but in summer in Yarımcin. Enterococci were also showed similar pattern with total coliforms in Yatakyeri and Yarımcin but winter was the season that exhibited higher value in Soğuksu. C. perfringens spores were detected in only Soğuksu spring in autumn and spring indicating that it may be originated from human and especially livestock activities. Being the best indicator parameter for faecal contamination, number of $E$. coli exhibited a strong seasonal variation in Yatakyeri, Soğuksu and Yarımcin springs. Difference in the numbers of E. coli in autumn and winter was clearly visible when compared with the number in spring and summer. Increased number of $E$. coli in spring must be because of the increase in rainfall and snow melting in this region causing more bacteria to pass through the soil into underground water reservoirs. Two reasons may be considered for higher contamination levels in summer, one of which may be increased human population size and another possibility is increased survival time of enteric bacteria in the environment. In contrast, relatively low level of contamination in autumn and winter may be a result of decrease in human population size resulting less faecal contamination and lower temperatures which limits the survival time of enteric bacteria in environment.

Distance of the springs from the settlement areas seems to be correlated with the degree of contamination. Keeping in mind the recent idea that total coliforms cannot be used as a reliable indicator for intestinal bacteria, only Harmancik spring, which is located at higher altitude than the settlement area, may be taken as not contaminated with the indicator bacteria. Contrarily Yarımcin spring was contaminated through the year even though it is located away from the settlement area but at lower altitude. The other two springs are situated in settlement areas and were densely contaminated accordingly. Contamination levels of those springs increase in accordance with the density of human and livestock populations. Indeed, Soğuksu spring exhibited heavier contamination than Yatakyeri spring especially in summer and autumn. Also enterococci and especially $C$. perfringens spore contamination was strikingly dense in Soğuksu spring located in the most populated area.

The results of this investigation show that all the natural springs were contaminated by bacterial indicators tested except for those which were located in higher latitude than the settlement areas. Most of the springs of the area are positioned more or less in populated areas, this means contamination with intestinally originated bacteria through the year with various densities. There is no sewage system in the area and not likely to be in near future because of sparse settlement tradition in the Blacksea Region. There is neither a water supply network nor an effective monitoring program. Although rare individual treatment systems are present, most of the population use raw natural springs for their drinking water supply and accordingly open to the exposure of possible pathogens which originate from gastrointestinal tract of human and warm-blooded animals. Certainly, the most urgent measure for the region is to build a clean drinking water supply. Even when a clean water network is constructed by local authorities, underground water reservoirs must be protected from microbiological, and of course also from chemical contaminations which are out of focus here. This is necessary for not only for protection of natural environment but also for the safety of natural springs in the area as an emergency water source.

\section{Acknowledgement}

This study was supported by the Research Fund of the University of Ondokuz Mayis, Samsun, Turkey, through the project PYO FEN 19041126.

\section{References}

[1] Chilton, J., Seiler, K.P., Groundwater occurrence and hydrogeological environments. In: Schmoll, O., Howard, G., Chilton, J., Chorus, I. (eds.) Protecting Groundwater for Health: Managing the Quality of Drinking-water Sources. WHO, IWA Publishing, London, 2006.

[2] Howard, G., Bartram, J., Pedley, S., Schmoll, O., Chorus, I., Berger, P., Groundwater and public health. In: Schmoll, O., Howard, G., Chilton, J., Chorus, I. (ed.) Protecting Groundwater for Health: Managing the Quality of Drinking-water Sources. WHO, IWA Publishing, London. 2006.

[3] Edwards, K.J., Becker, K., and Colwell, F., The Deep, Dark Energy Biosphere: Intraterrestrial Life on Earth. Annu. Rev. Earth Planet. Sci. 2012. 40:551-68

[4] Reith, F., Life in deep subsurface. Geology 39:287-288. 2011.

[5] Kleinsteuber, S., Schleinitz, K.M., Key players and team play: anaerobic microbial communities in hydrocarbon-contaminated aquifers. Appl Microbiol Biotechnol 94: 851-873. 2012.

[6] Rheinheimer, G. Aquatic Microbiology. $4^{\text {th }}$ edn. John Wiley\&Sons, Chiester, 1991.

[7] Brown, M.G., Balkwill, D.L., Antibiotic resistance in bacteria isolated from the deep terrestrial subsurface. Microbial Ecol 57:484-493. 2009.

[8] Balkwill, D.L., Reeves, R.H., Drake, G.R., Reeves, J.Y., Croker, F.H., King, M.B., Boone, D.R., Pylogenetic characterization of bacteria in subsurface microbioal culture collections. FEMS Microbiol Rev 20: 201-216. 1997.

[9] Roslev, P., Bukh, A.S,. State of the art molecular markers for fecal pollution source tracking in water. Appl Microbiol Biotechnol 89:1341-1355. 2011.

[10] Macler, B.A., Merkle, J.C., Current knowledge on groundwater microbial pathogens and their control. Hydrogeol J 8:29-40. 2000.

[11] Foppen, J.W., Schijven, J.F., Evaluation of data from the literature on the transport and survival of Escherichia coli and thermotolerant coliforms in aquifers under saturated conditions. Water Res 40(3):401-26. 2006.

[12] Pedley, S., Yates, M., Schijven, J.F., West, J., Howard, G., Barrett, M., Pathogens: Health relevance, transport and attenuation. In Schmoll, O., Howard, G., Chilton, J., Chorus, I. (ed.). Protecting Groundwater for Health: Managing the Quality of Drinking-water Sources. WHO, IWA Publishing, London. 2006.

[13] Gracias, K.S, McKillip, J.L., A review of conventional detection and enumeration methods for pathogenic bacteria in food. Can $J$ Microbiol 50: 883-890. 2004.

[14] Medema, G.J., Payment, P., Dufour, A., Robertson, W., Waite, M., Hunter, P., Kirby, R., Andersson, Y., Safe drinking water: An ongoing challenge. In: Assessing Microbial Safety of Drinking Water. OECD and WHO, IWA Publishing, London. 2003.

[15] Stevans, M., Ashbolt, N., Cunliffe, D., Recommendations to change the use of coliforms as microbial indicators of drinking water quality, Australian Government, Health and Medical Research Council. Biotext Pty Ltd, Canberra. 2003.

[16] Bartram, J., Pedley, S., Microbiological Analyses. In: Bartram, J.and Ballance, R. (ed), Water Quality Monitoring - A Practical 
Guide to the Design and Implementation of Freshwater Quality Studies and Monitoring Programme. UNEP/WHO, 229-255. 1996.

[17] Leclerc, H., Mossel, D.A.A., Edberg, S.C., Struijk, C.B Advances in the bacteriology of the coliform group: Their suitability as markers of microbial water safety. Annu Rev Microbiol 55:201-34. 2001.

[18] Szewzyk, U., Szewzyk, R., Manz, W., Schleifer, K.H., Microbiological safety of drinking water. Annu Rev Microbiol 54:81-127. 2000.

[19] Payment, P., Franco, E., Clostridium perfringens and somatic coliphages as indicators of the efficiency of drinking wate treatment for viruses and protozoan cysts. Appl Environ Microbiol 59(8):2418-2424. 1993

[20] Salem, I.B., Aouni, M., Mzoughi, R., Two five-plex PCRs methods for identification of common Salmonella spp. Serotypes. Ann Microbiol 60:135-141. 2010

[21] Purohit, H.J., Kapley, A., PCR as an emerginig option in the microbial quality control of drinking water. Trends Biotechnol 20 325-326. 2002.

[22] Noble, R.T., Weisberg, S.B., A review of technologies for rapid detection of bacteria in recreational waters. $J$ Water Health 03-4: 381-392. 2005.

[23] Yamazaki, Y., Fukasawa, A., Multiplex polymerase chain reaction method discriminating Escherichia coli and Shigella sp. Arch Microbiol 193:83-87. 2011

[24] Kubista, M., Andrade, J.M., Bengtsson, M., Forootan, A., Jona, J., Lind, K., Sindelka, R., Sjoback, R., Sjogreen, B., Strombom, L., Stahlberg, A., Zoric, N., The real-time polymerase chain reaction. Mol Aspects of Med 27:95-125. 2006.

[25] Arya, M., Shergill, I.S., Williamson, M., Gommersall, L., Arya, N., Patel, H.R.H. Basic principles of real-time quantitative PCR. Expert Rev Mol Diagn 5(2):2009-2019. 2005.

[26] Henegariu, O., Heerema, N.A., Dlouhy, S.R, Vance, G.H, Vogt, P.H., Multiplex PCR: Critical parameters and step-by-step protocol. BioTechniques 23:504-511. 1997.

[27] Heid, C.A., Stevens, J., Livak, K.J., Williams, P.M., Real time quantitative PCR. Genome Res 6: 986-994. 1996.

[28] Park, S.H., Hanning, I., Jarauin, R., Moore, P., Donoghue, D.J., Donoghu, A.M., Ricke, S.C., Multiplex PCR assay for the detection and quantification of Campylobacter spp., Escherichia coli O157:H7 and Salmonella serotypes in water samples. FEMS Microbiol Lett 316: 7-15. 2011.

[29] Kapley, A., Lampel, K., Prohit, H.J., Rapid detection of Salmonella in water samples by multiplex polimerase chain reaction. Water Environ Res 73(4):461-465. 2001.
[30] Smith, C.J., Osborn, A.M., Advantages and limitations of quantitative PCR(Q-PCR) based approaches in microbial ecology. FEMS Microbiol Ecol 67:6-20. 2009.

[31] Bej, A.K., Steffan, R.J., DiCesare, J., Haff, L., Atlas, R.M. Detection of coliform bacteria in water by polymerase chain reaction and gene probes. Appl Environ Microbiol 56(2): 307-314. 1990.

[32] TS EN ISO 9308-1, Su kalitesi- Escherichia coli ve Koliform bakterilerin tespiti ve sayımı. Bölüm 1: Membranla süzme yönetemi. Türk Standardları Enstitüsü, Ankara. 2004.

[33] Chapman, G.H., A culture medium for detecting and confirming Escherichia coli in ten hours. Am J Public Health N, 41:13811381. 1951.

[34] TS EN ISO 7899-2, Su kalitesi bağırsak enterokoklarının tespiti ve sayımı- Bölüm 2: membran süzme yöntemi. Türk Standardları Enstitüsü, Ankara. 2002.

[35] TS EN ISO 8020, Su kalitesi- Sülfit indirgeyen havasız ortam (anaerob) bakteri (clostridia) sporlarının aranması ve sayımı. Türk Standardları Enstitüsü, Ankara. 1997.

[36] Araujoa, M., Sueiro, R.A., Gomez, M.J., Garrido, M.J., Enumeration of Clostridium perfringens spores in groundwater samples: comparison of six culture media. J Microbiol Meth 57: 175-180. 2004.

[37] Sambrook, J., Russell, D.W. Molecular cloning a laboratory manual. $3^{\text {rd }}$ edn. Cold Spring Harbor Laboratory Press, Cold Spring Harbor, New York. 2001.

[38] Sharma, V.K., Dean-Nystrom, E.A., Casey, T.A., Semi-automated fluorogenic PCR assays (Taqman) for rapid detection of Escherichia coli O157:H7 and other shiga toxigenic E. coli. Mol Cell Probes 13: 291-302. 1999.

[39] Cheng, C.M, Lin, W., Van, K.T, Phan, L., Tran, N.N, Farmer, D., Rapid detection of Salmonella in foods using real-time PCR. $J$ Food Protect 71: 2436-2441. 2008.

[40] Ruxton, G.D., The unequal variance t-test is an underused alternative to Student's t-test and the Mann-Whitney U test. Behav Ecol 686-690. 2006.

[41] Ordu Halk Sağlığı Müdürlüğü, Ordu İli 2012 Yılına Ait İçme Suyu Analiz Sonuçları. 2013. [Online]. Available: (http://www.orduhalksagligi.gov.tr/wp/?page id=353 07.07.2013).

[42] Sağlık Bakanlığı, İnsani tüketim amaçlı sular hakkında yönetmelik. Resmi Gazete, Sayı:25730. 17 Şubat 2005 